\title{
Arti pamor në Normalen e Elbasanit (1909 - 2009).
}

\section{Zanafilla dhe kontributi kombëtar}

Bujar Kapllani

\section{Aktualiteti bashkëkohor i shkollës Normale}

E vonuar, por e arrirë erdhi Normalja në Elbasan. Shoqet e saj në Europë ishin në traditën e zhvillimit normal të sistemeve të edukimit, duke kaluar në eksperiencate bazave historike të mendimit njerëzor në2400 vite prej Platonit e Aristotelit dhe deri më sot, nga arti antik deri në artin postimpresionist. Shkolla jonë nuk lindi dot përgjatë shekujve XVII-XIX të zhvillimit të
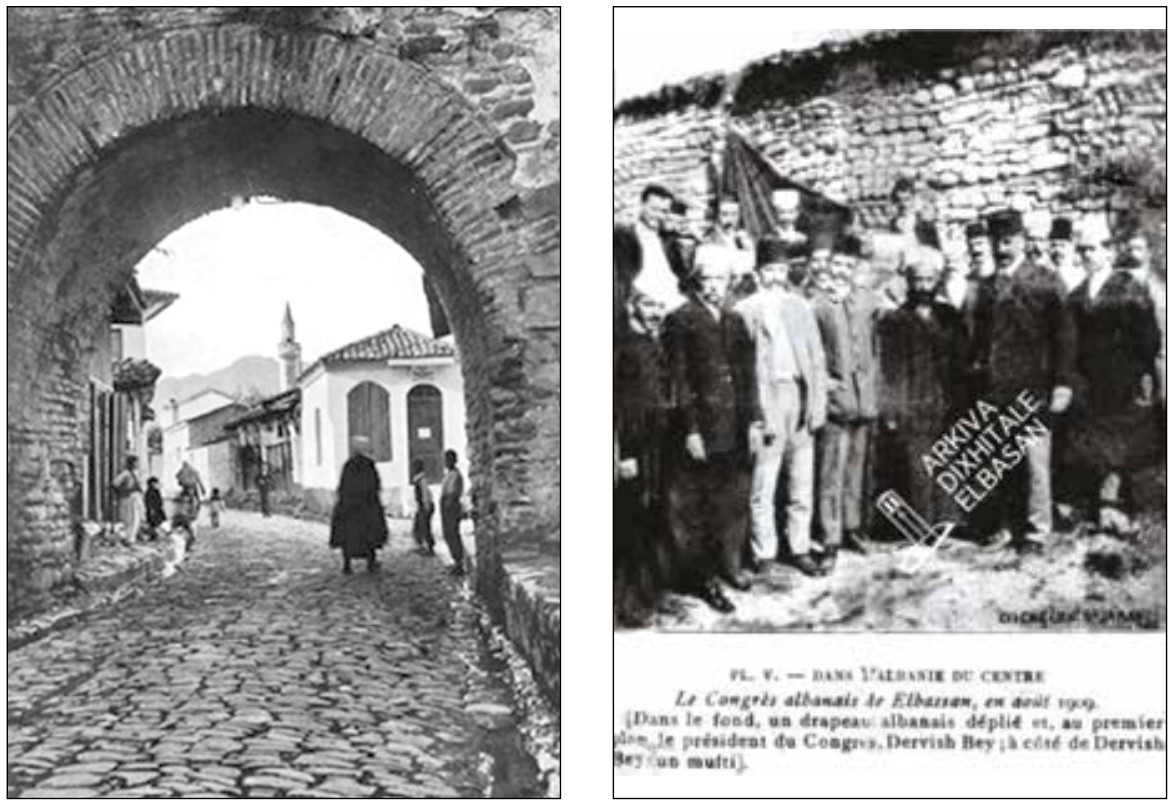


\section{Albanon}

Revistë etnokulturore

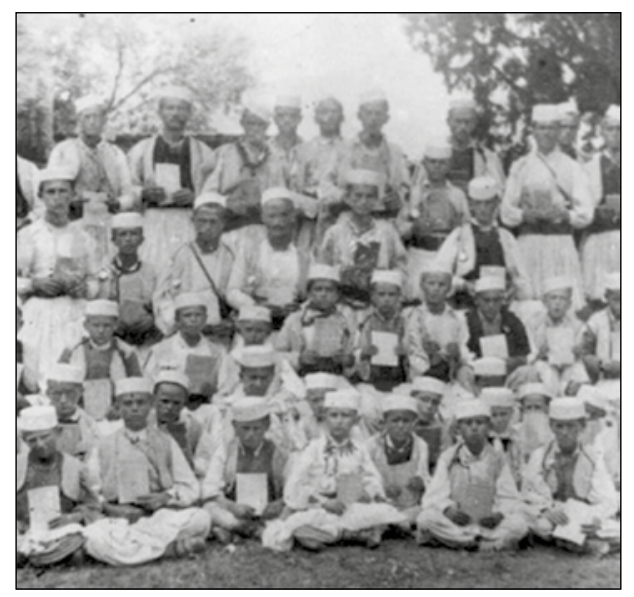

periudhës së parë të krijimit të mendimit modern e psikologjik, as gjatë periudhës së dytë kur ngriheshin Shkollat e Mëdha Europiane nën influencimin $\mathrm{e}$ programeve psikologjike përgjatë shekullit XIX. E gjithë kjo vonesë në kohë kushtëzohej nga sfondi historik i administrimit të jetës sociale e veprimtarisë kombëtare në trojet mbarëshqiptare. Ishim të sunduar.
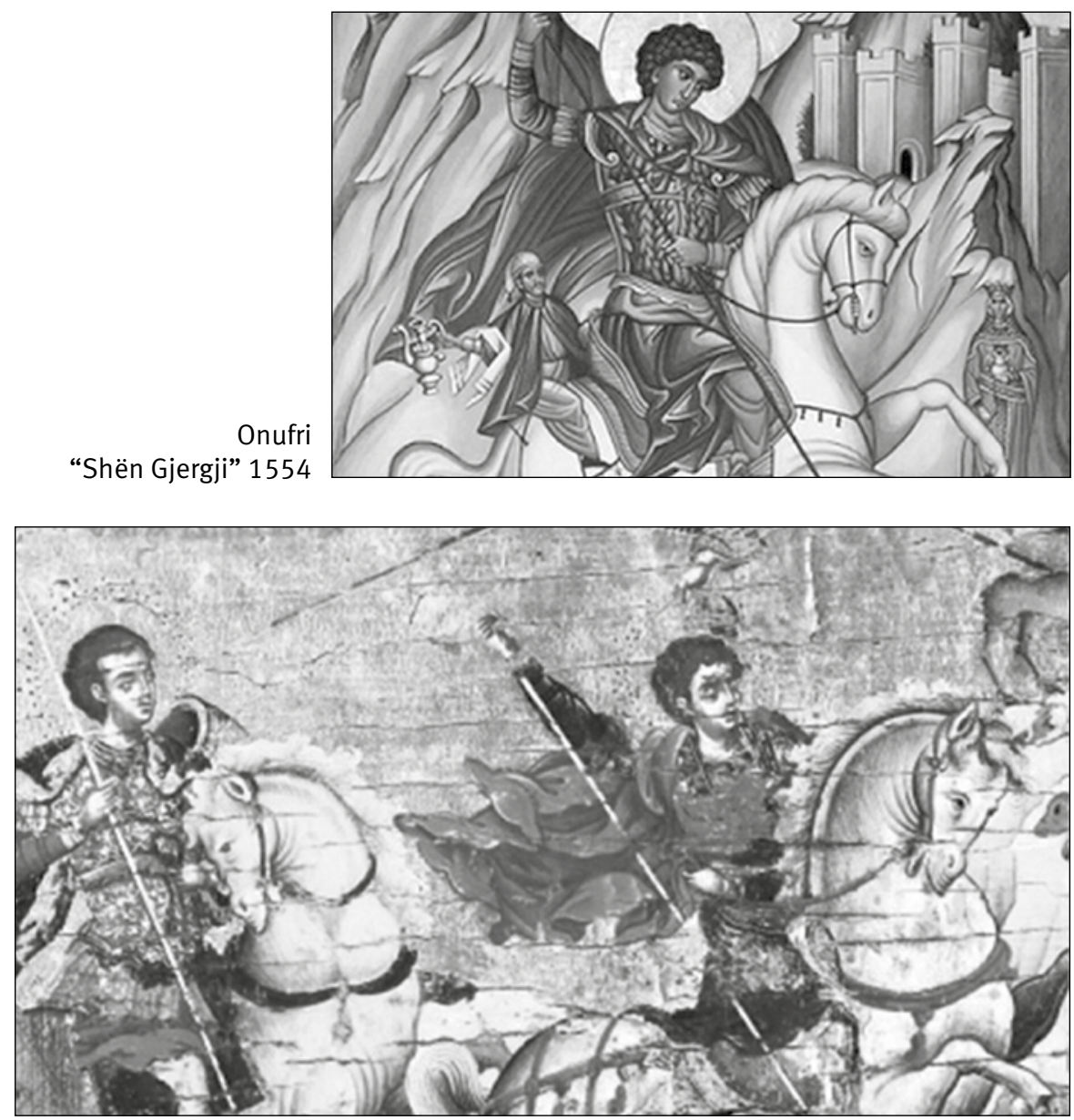

Anonim/atelieri i Onufrit “Shën Dhimitri dhe Shën Gjergji” Kisha Shën Dëllisë Korçë 


\section{Tradita e Arteve Pamore në Shqipëri}

Lidhur me Artet Figurative në krahinën e Elbasanit, që i përkasin kësaj periudhe, mbisundonte piktura me natyrë biblike, duke u mbështetur në stilin bizantin me një frymë kozmopolite për shkak të ideologjisë, ndaj dhe shumica e veprave dhe autorëve janë anonimë.

Onufri, emrin e të cilit mban dhe shkolla e arteve në Elbasan, pikturoi pamje nga Shqipëria; qytete shqiptare, folklorin shqiptar, fshatarë dhe veçanërisht luftëtarë. Një shembull mjaft i mirë në këtë rast është piktura e Shën Gjergjit, e cila pasqyrohet si një luftëtar përkrah Skënderbeut në luftën kundër turqve.

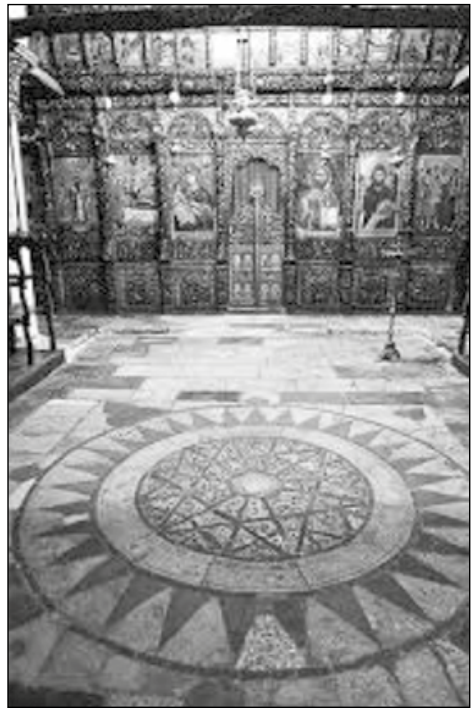

Në këto kushte pati përpjekje për ndërtimin e një fizionomie kombëtare të artit nga ky piktor shkëlqimtar i mesjetës, vepra e të cilit është nisja për të dalë nga anonimati. Me stilin e tij realist, Onufri $i$ afrohet stilit të Rilindjes Europiane, duke kapur botën e brendshme të modeleve të tij në pikturë, aq sa edhe në portretin e Davidit (Valsh-Shpat) ka mishëruar tiparet e korifeut të artit të Rilindjes, Mikelanxhelo. Davidi onufrian, të kujton "Padre Eterno" të Mikelanxhelos (V. Puzanova).

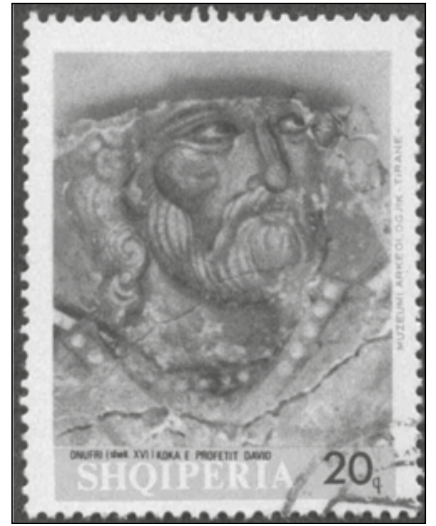

Onufri - "Davidi” - 1554

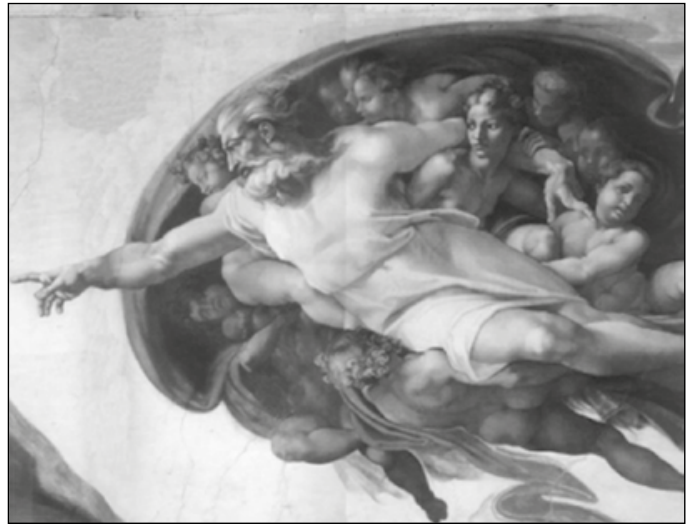

Mikelanxhelo - “Padre Eterno” - 1508 


\section{Albanon}

Revistë etnokulturore

Vepra e Onufrit në shekullin XVI, është një gur bazal jo vetëm për themelet e artit modern shqiptar, por edhe si një traditë e çmuar për të ardhmen. Kjo traditë u reflektua edhe në themelet e shkollës Normale, dhe pse ajo do të lindë pas tri shekujsh. Onufri shndërrohet sot në sytë tanë në një profet të së ardhmes, duke na lënë punimet në kishën e Shën Kollit në Shelcan dhe në kishën e Shën Premtes në Valësh (në vitin 1555), të shoqëruara me mbishkrime, ku veçmas na shtyn të mendohemi teksa i përfundon me fjalët “....më kujtoni dhe mua mëkatar Onufrin, prift, piktor dhe protopap i Neokastrës (Elbasani i sotëm)".

Në këtë frymë vlen të nderojmë dhe përmendim edhe piktorët e tjerë të mesjetës, me përmasa kombëtare për kohën (shek. XVIII-XIX), si Kostandin Shpataraku nga krahina e Shpatit, vëllezërit Kostandin dhe Athanas Zografi nga Korça, si dhe familja Çetiri (Gjergji \& Johan) nga Grabova e Elbasanit, që jetuan dhe punuan pikturat dhe afresket e tyre në Myzeqe. Me kontribute në Iluminizmin dhe Rilindjen Kombëtare, vjen piktori David Selenica nga Kolonja.
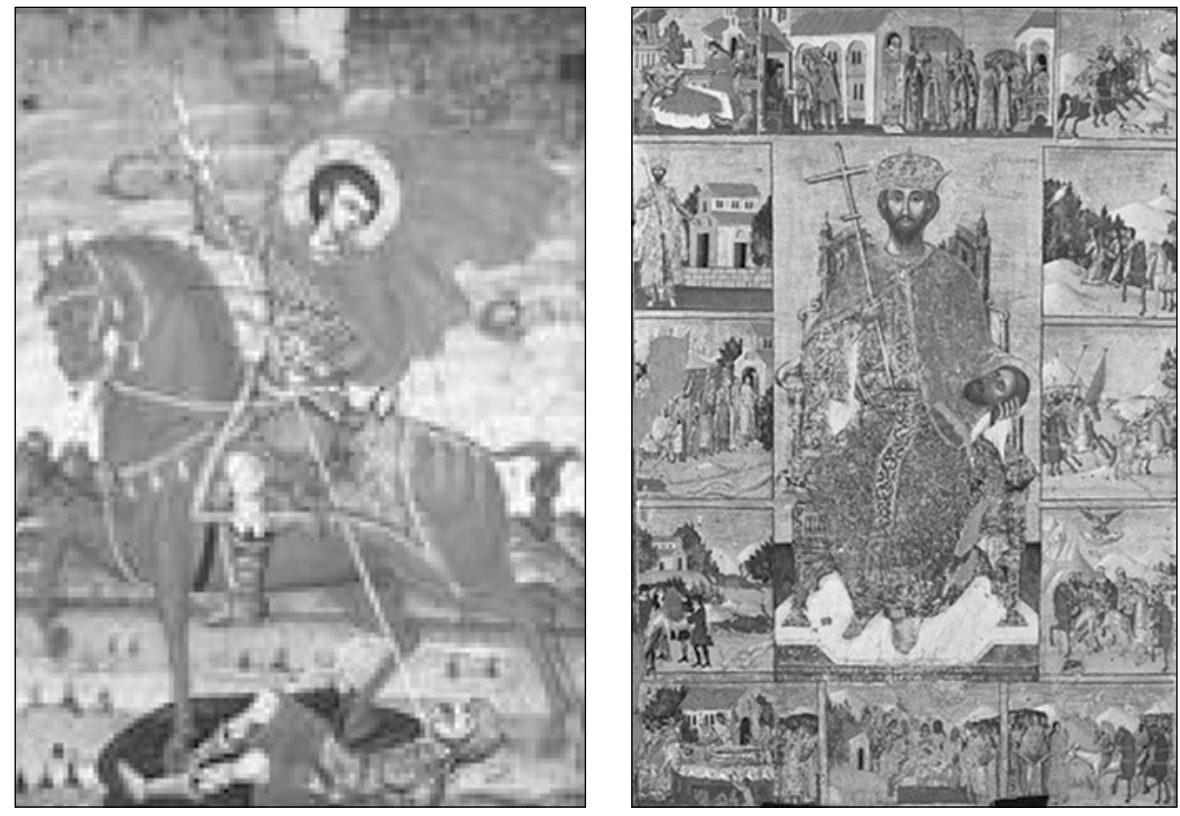

Kostandin Shpataraku

- “Shën Gjon Vladimiri”, Manastiri i Ardenicës

- “Shën Dhimitri”, Muzeu Onufri, Berat - shek. XVIII 
Athanas Zograf

- "Konstandini i Madh"
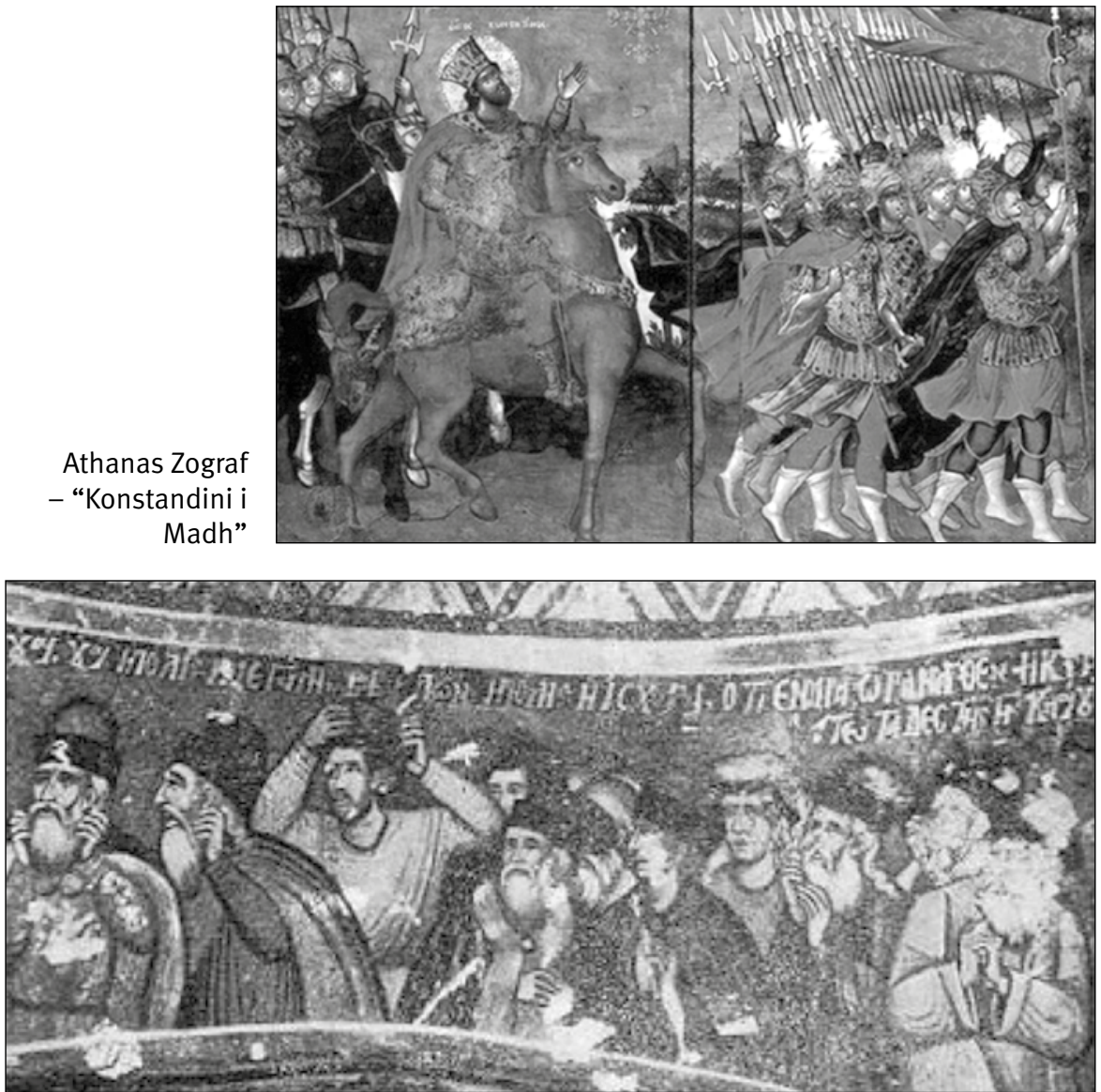

Kostandin dhe Athanas Zograf

- "Zjarri në Babiloni” - Kisha Shën Thanasi - Voskopojë
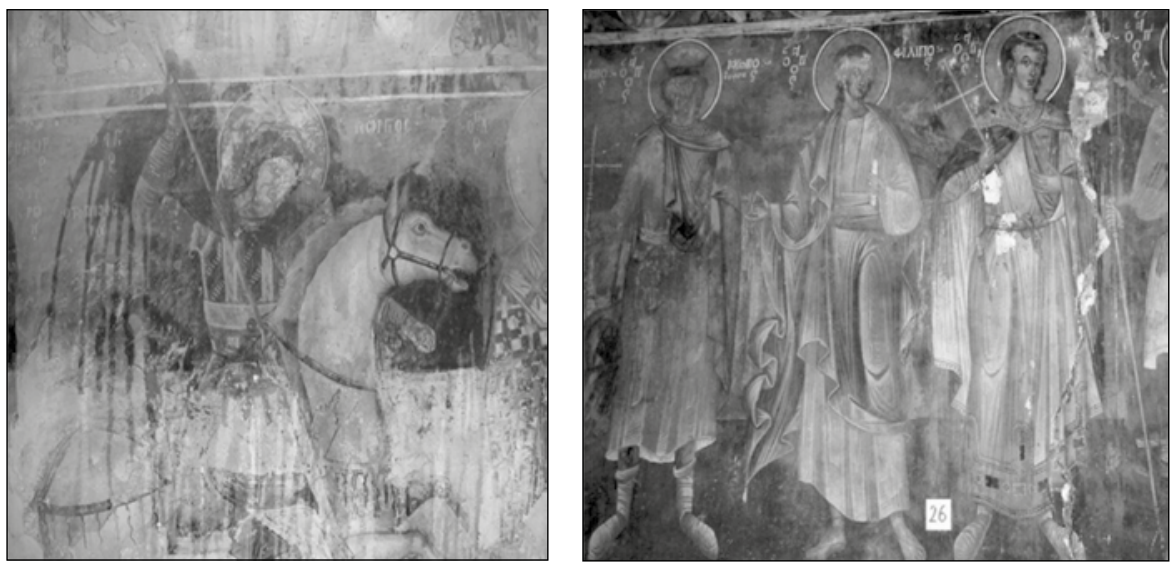

Gjergji dhe Johan Çetiri - Kisha Kozares Berat 


\section{Albanon}

Revistë etnokulturore
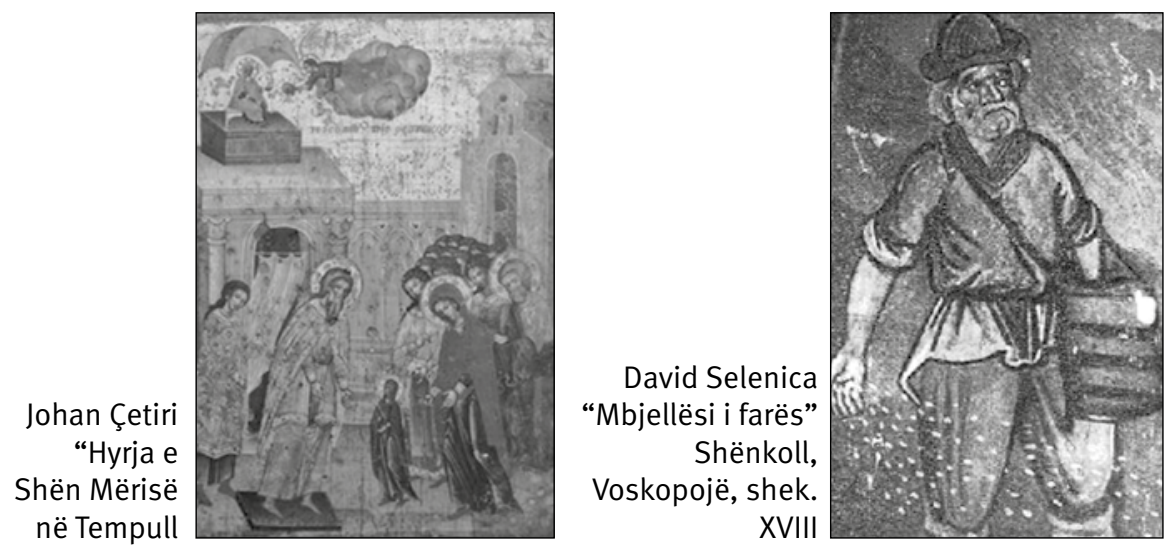

David Selenica

"Martirët"

-Shënkoll, Voskopojë, shek. XVIII

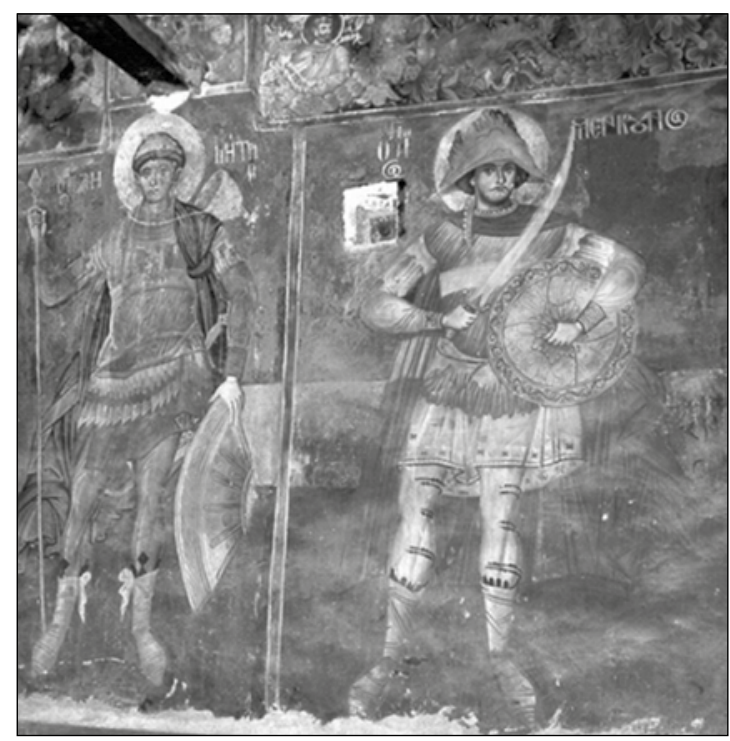

Në gjysmën e dytë të shek. XIX, fillon një etapë tjetër e rëndësishme për artin shqiptar. Lëvizjet e mëdha çlirimtare nga okupimi qindravjeçar osman, që sollën edhe Pavarësinë e Vendit (më 1912), krijuan atmosferën edhe për një drejtim të ri artistik, që të pasqyronte me realizëm jetën e përditëshme.

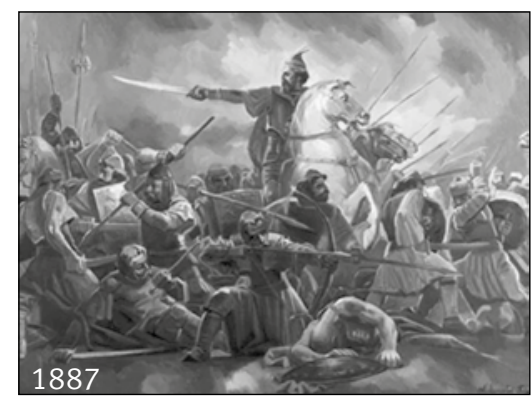

Në qytetin e Elbasanit artet figurative të fillim të shekullit $X X$ priren të përqafojnë influencën perëndimore, e cila përcillej nëpërmjet zhvillimeve të artit e kulturës në qytetet e tjera shqiptare, si Shkodra dhe Korça. Në këtë atmosferë shndërrimesh të mëdha për të ardhmen e kombit shqiptar, konstatojmë se në 


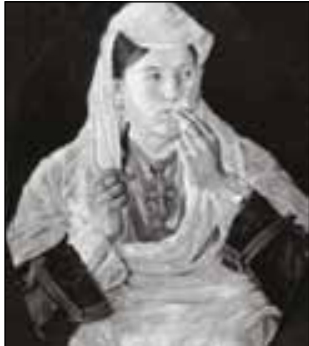

“Motra Tone” 1883

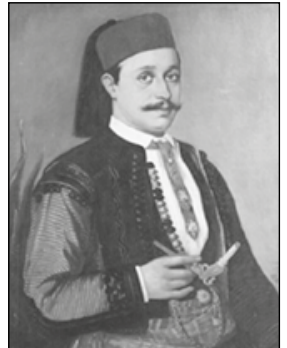

"Portret Burri"

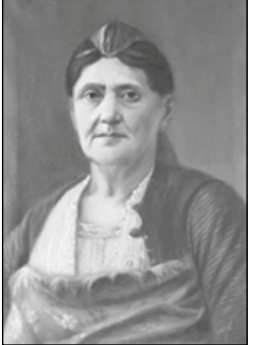

"Gjuzepina"

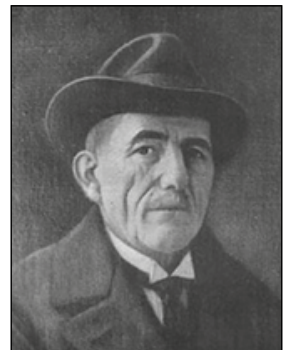

Kolë Idromeno

vitin 1883, u krijua portreti më i bukur në pikturën e Rilindjes Shqiptare, "Motra Tone" vepër e Kolë Idromenos (1860-1939) nё qytetin e Shkodrës ("Skënderbeu" realizohet më 1887).

Po këtë vit krijohet nga piktori korçar Jorgji Panariti "Portreti i Skënderbeut” (1883), në Malin

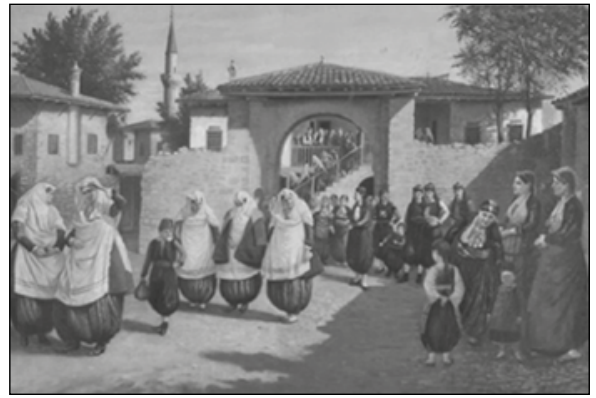

“Dasma shkodrane” 1924

Athos (1883). Piktura shqiptare nisi udhën e saj me dy portrete realiste dhe vendlindjet e këtyre dy artistëve të parë, Shkodra dhe Korça, u bënë vatrat kryesore e tiparit të zhvillimit të pikturës moderne në Shqipëri. Elbasani kishte kohë që ishte i orientuar në këtë tipar të lëvizjes për arsim, kulturë e art kombëtar.

Në Korçë ishte krijuar tashmë një brez i njohur artistësh, arti i të cilëve po shkëputej nga tematika fetare me stil postbizantin. Panariti ishte i pari që dha shenjën me portretin e Skënderbeut, më pas Theohar Gjini (1890) dhe Anastas Ballamaçi (1889) krijuan tablo për Skënderbeun.

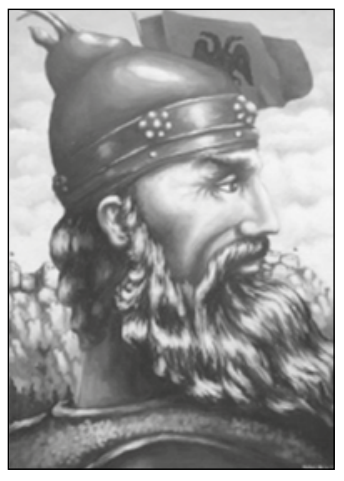

Jorgji Panariti "Portreti Skënderbeut”, 1883

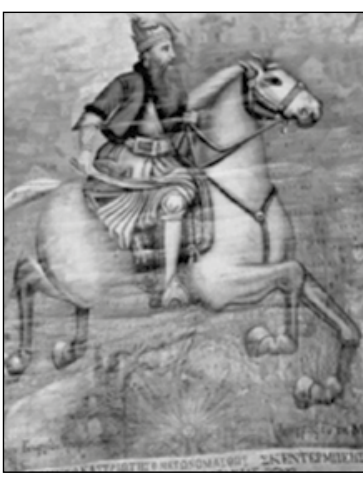

Theohar Gjini “Skënderbeu mbi kalë”, 1889

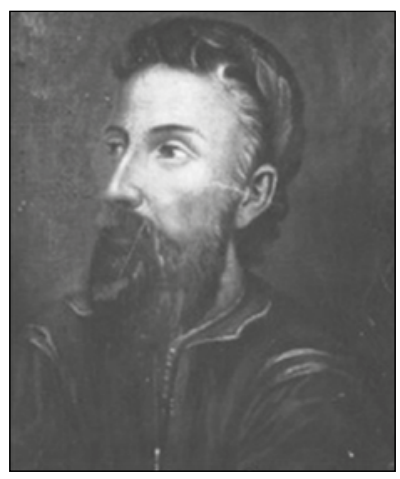

Theohar Gjini

“Skënderbeu”, 1890 


\section{Albanon}

Revistë etnokulturore
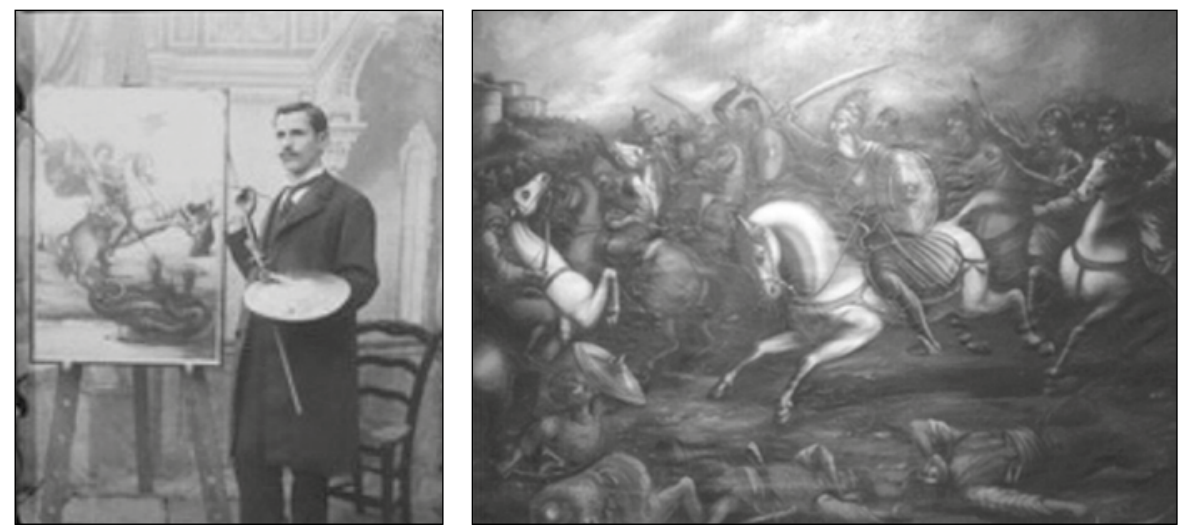

Vangjel Zengo “Skenderbeu” - 1933

Familja Zengo, me disa breza artistësh nga Dardha e Korçës, $u$ fut nëpikturën laike me Vangjel Zengon, ndërsa më vonë, dy vajzat Androniqi dhe Sofia, të parat artiste pamore femra në Shqipëri, iu përkushtuan plotësisht artit realist.

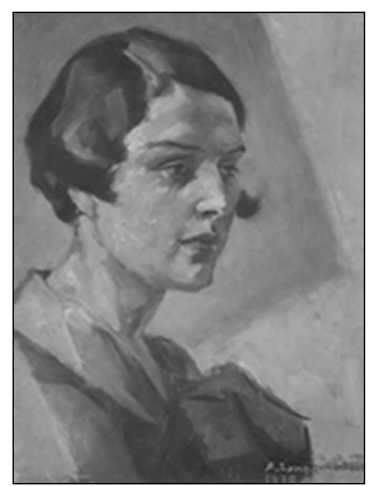

"Autoportret” Androniqi Zengo

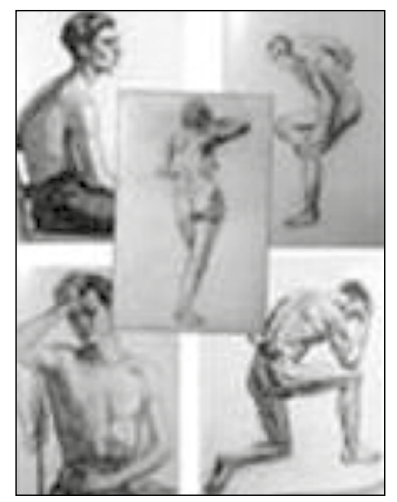

"Studime Trupore"

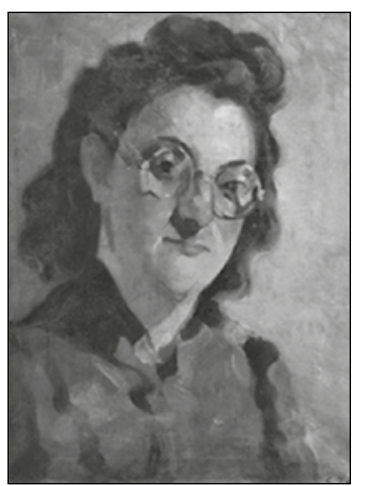

"Autoportret" Sofia Zengo, 1939

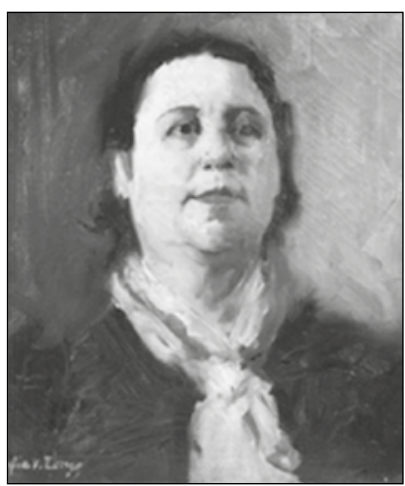

"Portret"

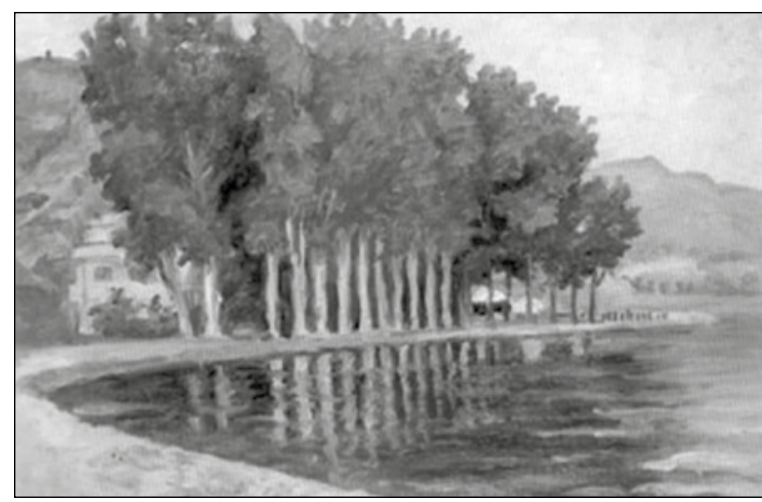

“Pogradeci” 
Por artisti më i shquar i Korçës dhe më i veçanti i gjithë Rilindjes Shqiptare, është Spiro Xega (1863-1953). Krijimtaria e tij i shërbeu jo vetëm çështjes kombëtare, me veprën “Gjergj Kastrioti” (1913), por solli një frymë të re edukimi me stilin dhe teknikën e pikturimit. "Çeta e Shabin Matrakut" (1930), është tabloja kompozicionale më e bukur e gjithë Rilindjes Shqiptare dhe e vetmja vepër që na pasqyron një aspekt jetësor të atyre viteve, e pikturuar direkt nga natyra, jashtë çdo skeme tradicionale.

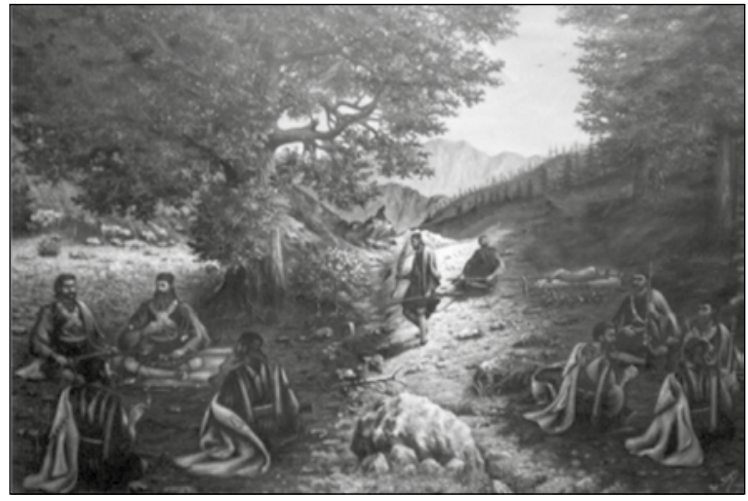

"Çeta e Shahin Matrakut"

Spiro Xega, 1930

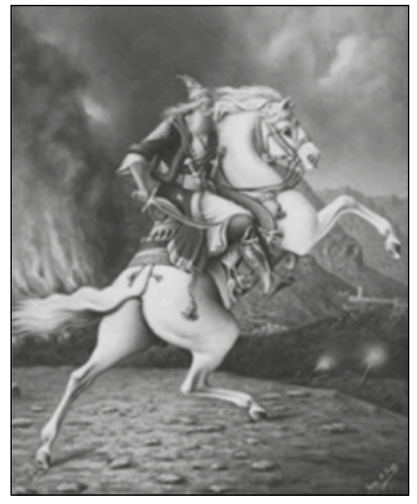

“Gjergj Kastrioti” Spiro Xega, 1913

Në Shkodër, nën influencën e artistëve italianë Saverio Polaroli dhe Pietro Marubi, ishte krijuar një atmosferë më e përshtatshme për zhvillimin e arteve. Ndoc Martini (1880-1917), Andrea Kushi (1884-1959), Simon Rrota (1887-1961) janë tre nga piktorët më të njohur që filluan krijimtarinë nën ndikimin e Kol Idromenos dhe bashkë me artistët e tjerë pasardhës të shquar, si Zef Kolombi (1907-1949) e bënë Shkodrën, për disa vite, vatrën më të rëndësishme të artit pamor shqiptar.

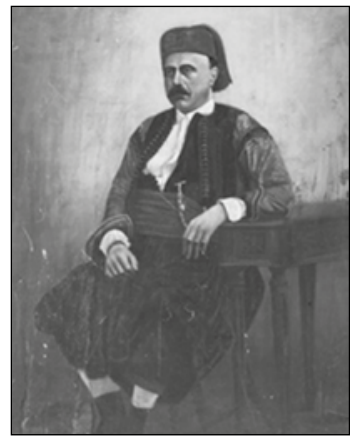

Pietro Marubi, Mikel Kodheli

“Kostum shkodran” 1897

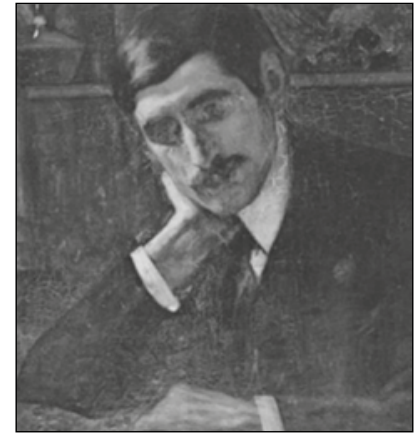

Ndoc Martini

"Doktor Prela”

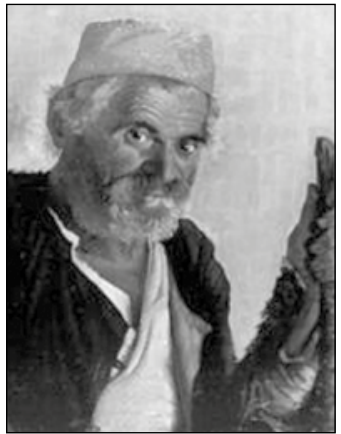

Andrea Kushi

“Bariu me shkop" - 1935 


\section{Albanon}

Revistë etnokulturore

Simon Rrota

“Te pusi i fshatit” - 1934

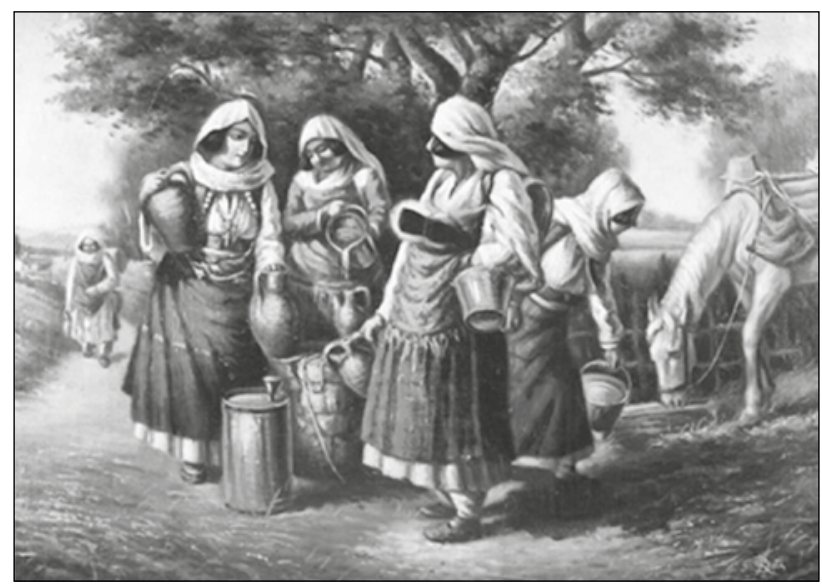

Kol Idromeno "Pamje nga Ulqini”, 1897
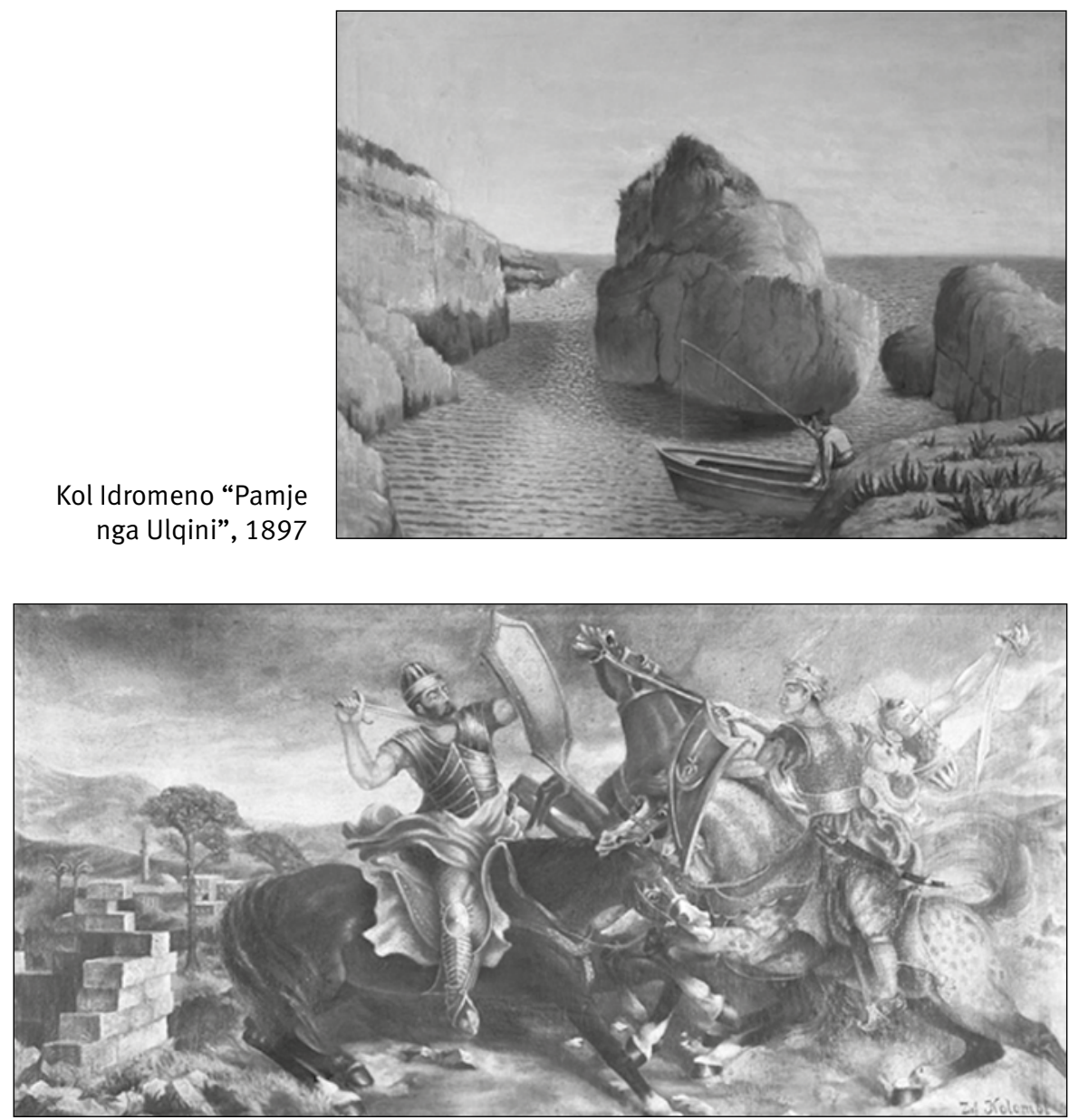

Zef Kolombi “Skënderbeu në luftim” - 1927 


\section{Lëvizje kombëtare për krijimin e shkollës Normale}

Në këto rrethana historike dhe ato politike të revolucionit dhe kushtetutës xhonturke (3-23 korrik 1908), janë krijuar kushtet objektive për të bërë të mundshme funksionimin real të periudhës së tretë në zhvillimin perëndimor të procesit të edukimit. Në këtë drejtim influencuan edhe Shkollat e Mëdha në shekujt XIX-XX. Ato ndikonin nëpërmjet programeve teorike dhe empirike, në zhvillimin e inteligjencës, përfshirë dhe angazhimet iluministe e patriotike të botës shqiptare. Nga këtu nis udha e shkollave të dijes në Shqipëri, Kosovë, Maqedoni, Çamëri e Mal i Zi.

Është ky stad zhvillimi historiko-kombëtar dhe social-kulturor që rriti ndërgjegjësimin e rilindasve shqiptarë që të organizojnë kongresin e gjuhës dhe arsimimit kombëtar. Janë pikërisht këto elemente të ndërgjegjes patriotiko-kulturore që përshpejtuan zgjidhjen e çështjes së Pavarësisë Kombëtare në trojet shqiptare.

Në shtator 1909, një vit mbas Kongresit të Manastirit (nëntor 1908), për unifikimin e gjuhës shqipe dhe dy muaj pas Kongresit të Dibrës (korrik 1909), i cili u keqpërdor prej xhonturqve, mbahet Kongresi Kombëtar i Elbasanit, ku u morën vendime të rëndësishme për zhvillimin arsimor e kulturor kombëtar në vend. Vendimi i hapjes së shkollës Normale Elbasan më, 1 Dhjetor 1909, ishte jo vetëm me rëndësi të madhe për Lëvizjen Kombëtare Shqiptare, por edhe për hapjen e një rruge emancipimi modern të kulturës dhe artit në pjesën jugore të kontinentit europian.

Alfabeti i Kristoforidhit zbriti mjeshtrat shkodranë të pikturës në zemër të atdheut, atje ku rilindasit vendosën të ngrenë shkollën Normale, në Elbasan. Kjo shkollë mblodhi mendjet më të ndritura të kombit, ashtu si mendonte edhe Faik Konica në letrën që i shkruante Aleksandër Xhuvanit (27 nëntor 1908) për organizimin e Kongresit të Elbasanit.

\section{Arti pamor shqiptar, pjesëmarrës real në edukimin e nxënësve në shkollën Normale}

Artet dhe vizatimi morën rëndësi të madhe në standardizimin e edukimit të qytetarisë europiane nëpërmjet zgjerimit dhe influencimit të eksperiencave artistike në shekujt XIX-XX. Kjo shkollë, me plot bindje mund të vlerësohet jo vetëm paraardhëse e Universitetit “Aleksandër Xhuvani”, e shkollës artistike "Onufri" Elbasan, por edhe paraardhëse e Liceut Artistik dhe Akademisë së Arteve Tiranë, me meritën e mjeshtrave të pikturës që u punësuan në këtë 


\section{AlBanon}

Revistë etnokulturore

Normale dhe me faktin se lënda e vizatimit u institucionalizua në procesin arsimor shqiptar.

Mësuesit që zhvilluan lëndën e vizatimit dje në Normale (sot UE), janë emra artistësh që zënë një vend të rëndësishëm dhe të papërsëritshëm në fondin e arsimit dhe kulturës kombëtare. Ata ishin mësues dhe pedagogë, që zbatonin parimet pedagogjike të kohës që përfaqësonin, të aftë e me vizion për mësimdhënien e artit pamor.

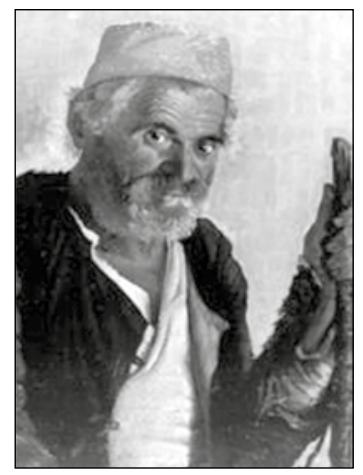

Andrea Kushi

“Bariu me shkop" - 1935

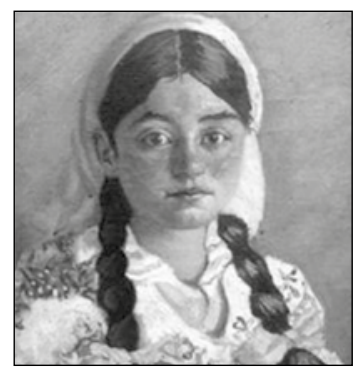

Andrea Kushi

"Vajza me kostum popullor elbasanas" - 1930

Mësuesi i parë i vizatimit në Normale, është piktori i parë realist që vjen në qytetin e Elbasanit; ai është 32-vjeçari shkodran (mosha kur ai ishte mësues në Normale), mjeshtri Andrea Kushi (1884-1959), i cili njihet në historinë e artit me kompozimin "Plaku me shkop". Pikturë tjetër që njihet është "Vajza me kostum popullor elbasanas", portrete dëshmorësh, figura shpatarakësh, etj. Është pjesëmarrës i ekspozitës së parë për piktorë profesionistë në qytetin e Elbasanit, ajo e 100-vjetorit të ditëlindjes së Naim Frashërit, në maj 1946. Shtëpia e tij në Shën Koll tek Beçajt, u shndërrua në një galeri private për banorët $e$ atëhershëm të qytetit. Galeria përfshinte hajatin poshtë, çardhakun dhe një dhomë të tërë (Hyjni Ceka - "Lule më lule e këngë më këngë" - fq.44).

Andrea Kushi ishte mësuesi që formoi bazat e para të mësimdhënies në lëndën e vizatimit (1916), duke u bazuar në teoritë e kohës mbi zhvillimin e përgjithshëm të mendimit, të cilat kërkonin, sipas teorisë së Charles Spearman 1904 - se inteligjenca mund të zhvillohet në sajë të trajtimit të çështjeve si krijimtaria, personaliteti, karakteri, dija dhe urtësia.

Shkolla Normale, në këtë kohë të Andrea Kushit synonte "inteligjencën e përgjithshme", formuar dhe përshtatur objektivisht në një sistem të klasifikimit të objekteve dhe natyrës në lëndën e vizatimit. Ai futi në procesin e mësimdhënies teorinë dhe metodikën e të vizatuarit të objekteve dhe natyrës, duke evidentuar në shkollë kulturën qytetare, kënaqësinë e të qenit origjinal dhe

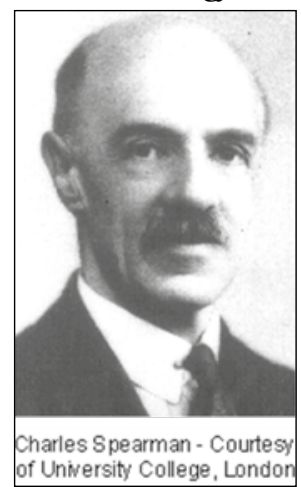


krijues, debatin dhe argumentimin teorik dhe krijoi aftësinë për të testuar njohuritë teorike me kërkime praktike. Temat kryesore ishin natyra dhe mendimet e ndryshme njerëzore, të cilat po fitonin një interes të gjerë në edukimin publik në Normale, duke krijuar diferencimin e personalitetit të nxënësve në prezantimin mësimor dhe edukativ të tyre, në varësi të kërkesave të punësimit.

Andrea Kushi ka meritën e themeluesit të artit modern në qytetin e Elbasanit, duke e binjakëzuar tashmë me kulturën shkodrane dhe europiane në artet pamore. Dhe prej këtij pozicioni tashmë të rëndësishëm për kulturën tonë kombëtare, siç është Elbasani, e shtrin veprimtarinë e tij në qytetin e Tiranës, duke hapur në 1931 kursin e parë të vizatimit, i cili u shndërrua në shkollën e parë të artit pamor në Shqipëri. Si rezultat, pati meritën të organizojë në 1931 të parën ekspozitë kombëtare në Shqipëri.

Në të tilla rrethana, shihet të rritet edhe interesi i masës për kulturën dhe artet, dhe Shkolla Normale të formonte dhe shpërndante misionarët e dijes në kombin shqiptar. Ky do të ishte institucioni i parë arsimor e modern që do të bëhej bashkëudhëtar me periudhën e katërt të zgjerimit të teknikave të reja statistikore dhe planifikimit modern të eksperimentimit si dominim i teorisë, "Inteligjenca e shumëfishtë" në gjysmën e parë të shekullit XX, frymë që përcillet në teorinë e Luis Thurstone (1938), që mbështet ndarjen e inteligjencës në shtatë

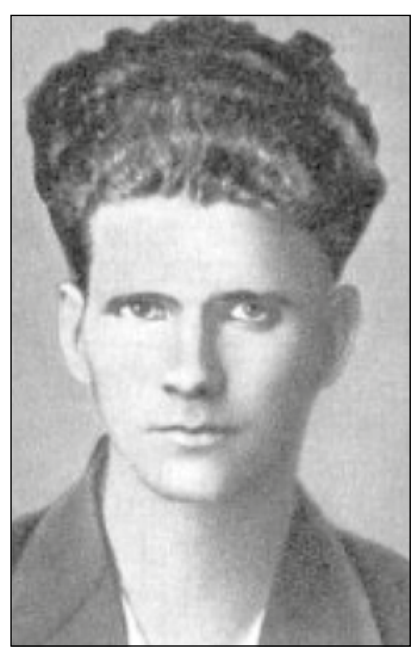
drejtime kryesore

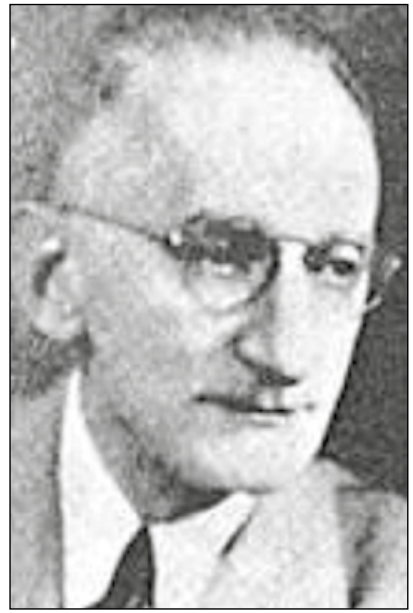

Luis Thurstone të pavarura: shprehja e mendimeve dhe ideve me fjalë, shprehja me të folur, aftësia matematikore, kujtesa, perceptimi i shpejtësisë, arsyetimi, hapësira pamore.

Këto janë vitet e lulëzimit të Normales, kur një trashëgimtar i ri i kulturës shkodrane merr stafetën e Kushit në 1933. Ky djalosh 26-vjeçar ishte Zef Kolombi, i cili emërohet profesor i vizatimit, sapo mbaron studimet në Akademinë e Arteve në Romë. Ishin vitet 30-40 dhe ai punoi në Elbasan, duke 


\section{Albanon}

Revistë etnokulturore

kontribuar me aktivitetin profesional në pikturë dhe mësimdhënie në Normale. Piktori i madh shkodran, Zef Kolombi, dëshmon për përmasat kombëtare të shkollës, por mbi të gjitha për rëndësinë absolute të lëndës së edukimit artistik në përgjithësi. Në këtë periudhë, shkolla bazohej në teoritë e materializmit mekanik, duke i kushtuar më tepër vëmendje observimit material të formave, dritës, linjave etj., nëpërmjet "perceptimit”, “vëmendjes”, “imagjinatës", "zbavitjes" me metodën e kopjimit në atë disiplinë mësimore, që ne e quajmë Vizatimi nga Natyra. Edukimi artistik konsiderohej si një trajtim mendor, ku aftësia krijon shtysat kryesore për të ardhmen, në shkallët e pafundme të formimit.

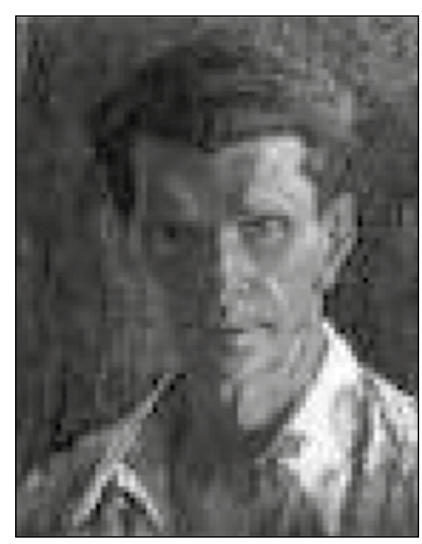

"Autoportret"

Zef Kolombi, 1947
Z. Kolombi i meritoi titujt "Mësues i merituar", "Piktor i merituar" dhe "Piktor i Popullit", jo vetëm për seriozitetin e plotë në punë, njohjen e thellë të problemeve në edukimin artistik, por edhe si piktor i peizazhit, natyrës së qetë dhe portretit që sollën risi në artin shqiptar, duke qenë shumë kërkues ndaj vetes deri në atë nivel sa të ketë meritën e evidentimeve psikologjike dhe koloristike në pikturën e tij. Zef Kolombi, psikolog i thellë dhe kristalor në strukturën koloristike, iku 42 vjeç, një humbje kjo e madhe, për artin shqiptar në të cilin ai premtonte shumë, nëse do të jetonte më gjatë.

Kam besimin se cilido brez që vjen pas, ka për të ndjerë adhurimin më të lartë për të dhe kontributet e tij në evolucionet cilësore të Normales, e cila nuk do të kishte lënë gjurmë pa emra të tillë si Kolombi. Në librin biografik "Lule më lule e këngë më këngë" (fq.41) të profesorit dhe shkrimtarit elbasanas, Hyjni Ceka, gjejmë adhurimin e tij për personalitetin e Kolombit:

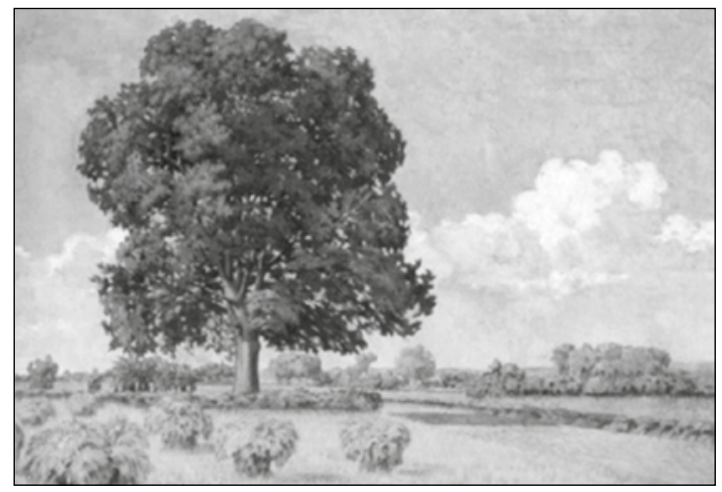

“Koha e korrjeve”, 1940 
“... Por, e kujtoj... Se më ka qenë ngulur në mendje, që nga ato kohërathellë. Bëhen shtatëdhjetë vite. Ndoshta më tepër. Më ngelet peng veç për një gjë. Si nuk u bë i gjallë një elbasanas e të kish thënë dy fjalë për Zef Kolombin?! I kemi hyrë në hak. Jo se u shkri për Elbasanin... Por u shkri për këtë qytet...Bashkë! Elbasanas, njëzet e katër karat! E pat marrë mbarë... Nga s'e nguli atë kavalet të uruar! Në Qoshe, ke Gjirizi, ballë për ballë me shkëmbin e Letanit... Në Tabake, ke Çardhaku, përballë me Krastën e Madhe... Ke Gjurma Mushkës... Ke Tri Urat. Nëpër tablo e mblodhi gjithë. Që nga Ullishta e deri buzë Shkumbini. Kush e bëri këtë?!...S’e bëri djali yt, o Elbasan. Por, Zef Kolombi.”

“Natyrë e qetë, rrush e pjeshkë"- 1940

“Rrugicë në Elbasan”, 1938
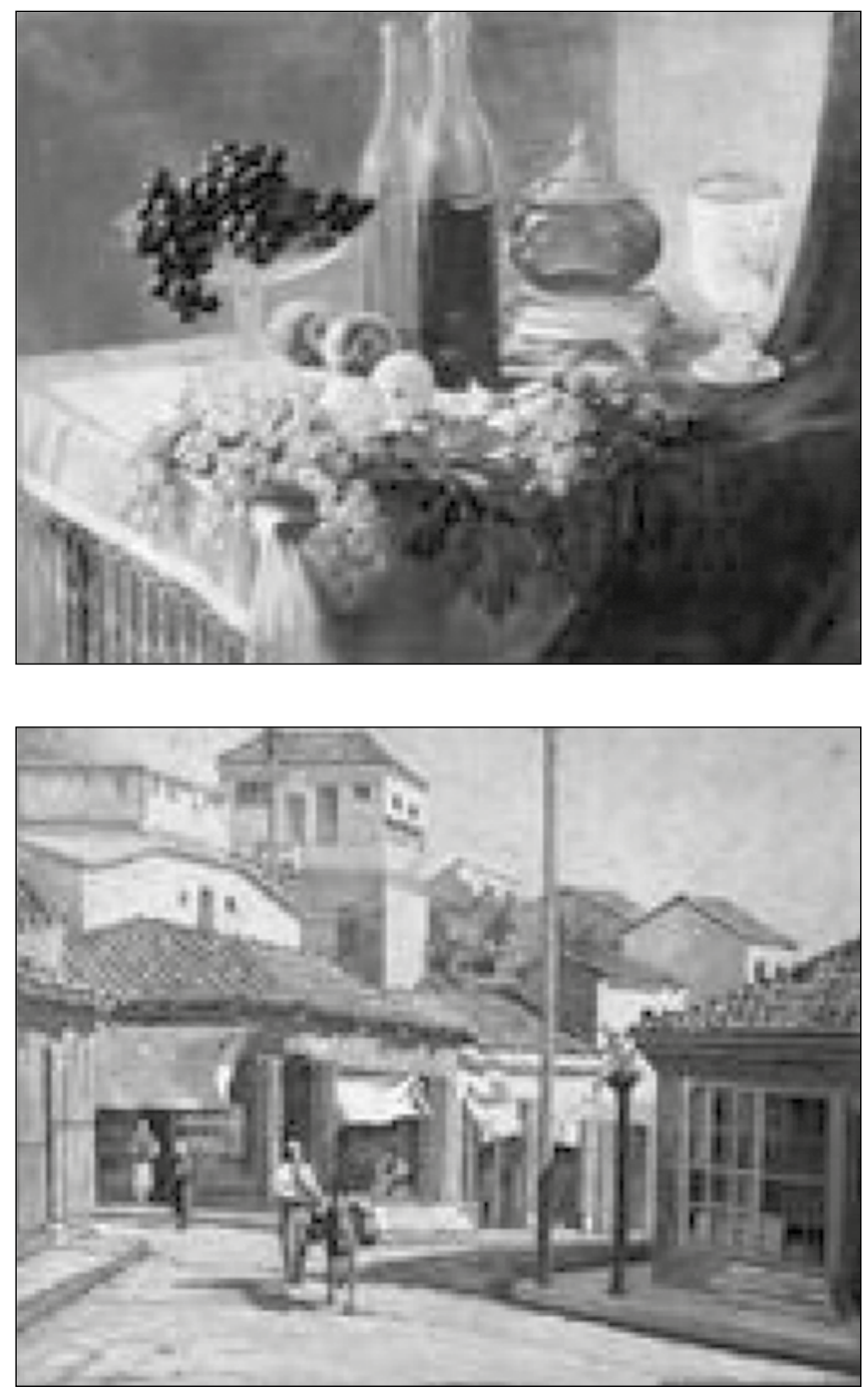


\section{Albanon}

Revistë etnokulturore

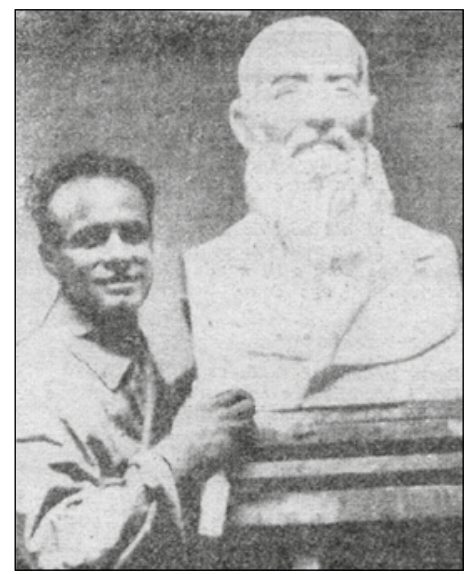

Gjatë viteve '30, kur drejtor i saj është Aleksandër Xhuvani, shkolla Normale, duhet të jetë zgjeruar si asnjëherë tjetër. Kjo duket në faktin se Z. Kolombi gjeti aty A. Kushin me të cilin punoi 2 vite, dhe pas largimit të Kushit vjen një tjetër djalosh i ri nga Korça, 29 vjeçari Dhimitër Çani. Kreu studimet në shkollën e mesme franceze, për të vazhduar studimet në SHBA. Ai la mbresat e njeriut me shije dhe fizik atleti, përfundoi shkollën sportive në Boston (1922-1932). Krijon miqësi me Fan Nolin, ndërkohë merret me muzikë, teatër dhe fotografi, gjë e cila e shtyu më pas të ndjekë studimet në Akademinë Britanike të Arteve në Romë (1932-1935). Në përfundim të studimeve, u dekorua. Fryma e atdhetarisë, ashtu si edhe e Kolombit, e bëri të niset drejt Shqipërisë. Për Normalen, prania e skulptorit Dh. Çani, i cili merret me sport, muzikë, teatër dhe fotografi ishte një shans për kohën. Ishte viti 1936. Gjatë kësaj periudhe ai realizon Monumentin e Dëshmorëve të Kombit në Berat (1935) dhe Skënderbeun (1937). Në 1950 vendoset në Tiranë, me punë në gjimnazet e saj. Në krijimet e tij ka modeluar monumente dhe relieve, por më tepër dallohet në realizimin e busteve. Ka modeluar më shumë se 200 të tilla, duke paraqitur njerëz të famshëm apo të zakonshëm, familjen e tij ose miqtë, si dhe autoportretin e tij, në periudha të ndryshme të jetës. Ai ka hapur tri ekspozita personale në vitin 1962 dhe 1975 në Tiranë, në vitin 1985 në Korçë. Veprat e tij gjenden kudo në Shqipëri.

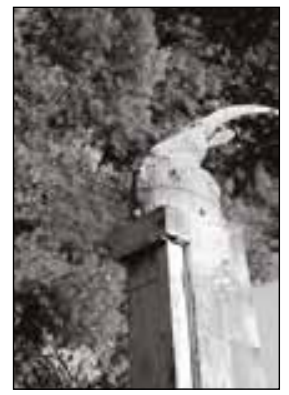

Dhimitër Çani, “Skënderbeu”, 1937

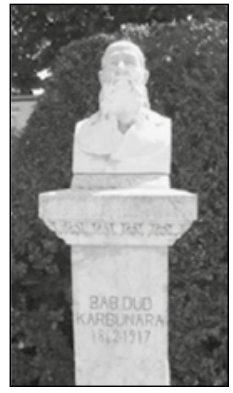

Dhimitër Çani

"Babe Dud Karbunara”, 1937

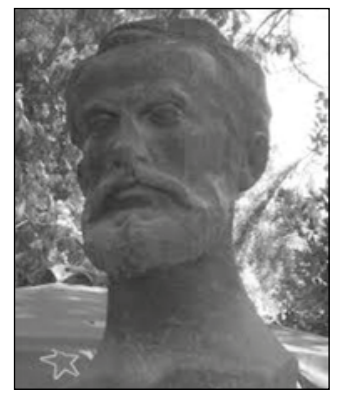

Dhimitër Çani

"Sami Frasheri”, 1960

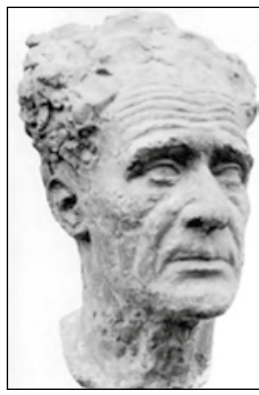

Dhimitër Çani

"Nonda Bulka", 1969 
Disa dekada më vonë, piktori elbasanas Xh. Lufta do ta përshkruante takimin me të si më poshtë; “...i thyer në moshë, por me një zemër të re, ai fliste me plot pasion për shkollën ku kish dhënë mësim. Ai u bë për mua simbol frymëzimi se me giithë vështirësitë e jetës, duke mos $i$ shtrirë dorën kërkujt, me djersën e ballit, kish çarë përpara dhe ish optimist për të vazhduar pa ndërprerje punën në studion e tij".

Çani ishte miku i F. Nolit në rininë e tij, ndaj dhe veprat e krijuara gjatë jetës i kushtohen figurave si: Bab Dud Karbunara (1937), Naim Frashëri (1956), Vasil Shanto (1956), Ushtari i Popullit (1957), Avni Rustemi (1959), Sami Frashëri (1960), Ndre Mjeda (1961), Pjetër Budi (1963), Ali Asllani (1964), Fan Noli (1965), Koto Hoxhi (1965), Milto Sotir Gurra (1969), Nonda Bulka (1969), Loro Kovaci (1969), Abedin Cici (1972), dir. M. Krantja (1974), etj.

Pas këtyre artistëve, pinjollë të Rilindjes Kombëtare që kontribuan në portretizimin e Normales, simotër e arsimit të lartë shqiptar, vjen kontributi i artistëve elbasanas të cilët e zhvilluan aktivitetin e tyre pedagogjik në Normalen e pas Luftës II Botërore, në vazhdimësinë me emrin "Shkolla Pedagogjike", "Instituti i Lartë Pedagogjik" dhe pas viteve '90 me ndryshimet demokratike "Universiteti i Elbasanit". Aktiviteti i këtyre artistëve hapet me Bukurosh Sejdinin, Vasil Tolin dhe vazhdon me emrat e piktorëve Andon Lakuriqi, Xhemal Lufta, Fatbardh Marku, Bujar Kapllani, Luan Qose, Ibrahim Zabzuni, Dhimitër Telezi, Spiro Panariti, por dhe emrat e piktorëve të nderuar elbasanas që hapën një shkollë profesionale të pikturës e skulpturës, ku vlen të përmenden B. Sejdini, Andon Lakuriqi, Isuf Sulovari, Sigfrid Mullisi, Shpëtim Arapi, Ylli Haruni, Ismail Cani, Kujtim Koprencka etj...

Kjo periudhë korrespondon me periudbën e fundit dhe tëpestë të zhvillimit të etapave në pedagogjinë botërore, në vazhdimin e përpjekjeve me tendencë teorinë e njohjes dhe kërkimin e thelluar në përfshirjen e përpunimin e njohurive më shumë komplekse dhe të një mendimi për të shfrytëzuar prova normale në vlerësimin e dijes. Shfaqja e kërkimi i metodave gjenetike dhe neurologjike të besueshme, krijon mundësinë e studimit të veçorive të rrethanave biologjike e psikologjike të inteligjencës njëkohësisht, zhvillimin e inteligjencës intuitive. 